\title{
الفضاء الكرونوتوبي في قصيدة "أغنيّة البجع" لممدوح عدوان
}

مه د. رسول بلآوي

كايّة الآداب والعلوم الإنسانيّة / بولوشهر -إيران)

\begin{abstract}
: المنصص:

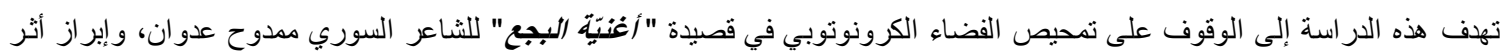

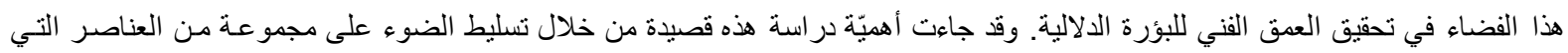

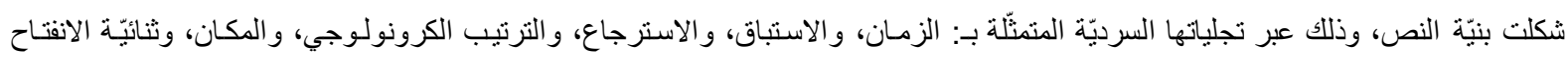

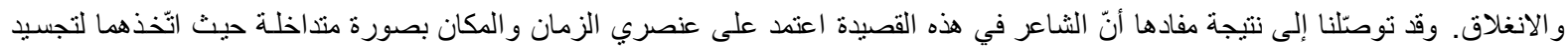

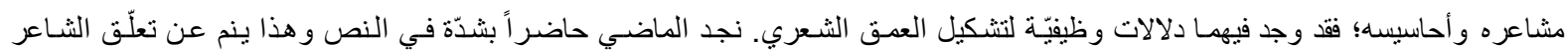

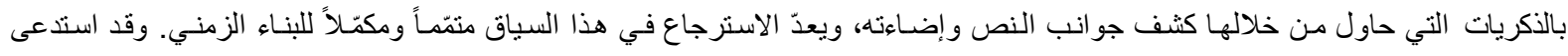

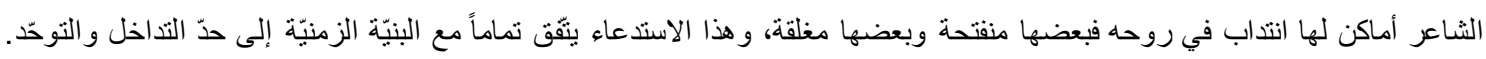

الكلمات الاليلية: الفضاء الكرونوتوبي، الزمان، المكان، ممدوح عدوان، قصيدة "أغنيّة البجع".
\end{abstract}

الإقدمهة:

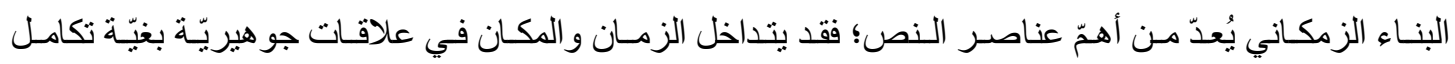

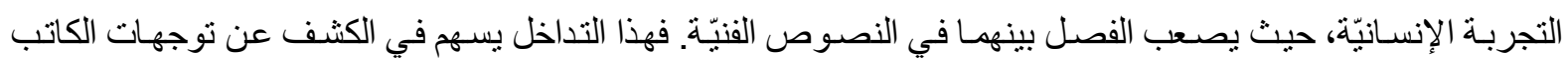

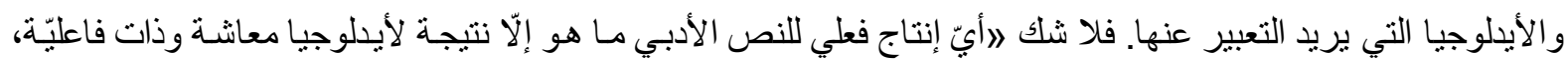

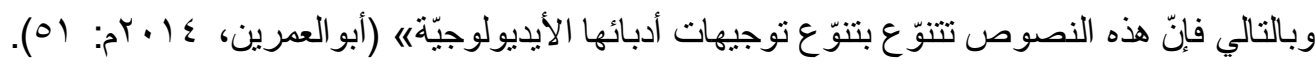
بحثنا هذا سيتناول فضـاء الكرنوتوب ودوره في تشكيل البنـاء الزمكاني. فقد وجدنا الثـاعر يستخدم عنصـري

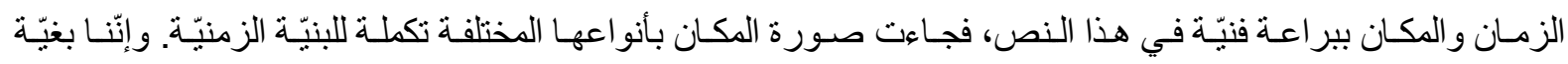

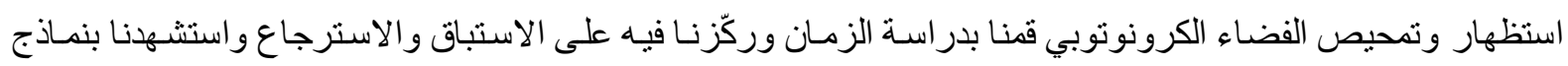
من شعر مدوح في قصيدته المدروسة أيّ "أغنيّة البجع"؛ ثم عرّجنـا للمكان ودرسنا فيه ثنائيّة الانفتـاح و الانغـلاق فهنالك

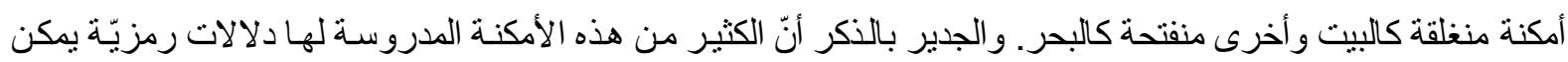

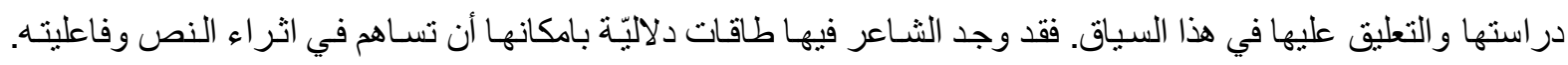
وقد حاولنا بقدر المستطاع أن نكثف عن هذه الدلالات المقصودة في النص.

أسئلة البمث:

في هذه الدراسة سوف نحاول الإجابة عن الأسئلة التالية: ـ كيف تمظهر الفضاء الكرونوتوبي ومستوياته في قصيدة "أغنيّة البجع" لممدوح عدوان؟ ـ ما مدى أثر نلك التمظهر، والبناء الفني و الجمالي على المتلقي؟

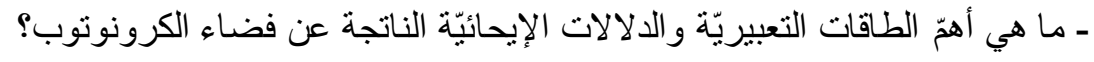

أهداف الدوراسة:

تحاول هذه الدراسة توضيح الأهداف التاليّة: ـ الوقوف على كيفيّة نوظيف الزمان و المكان، والتوحّد بينهما في قصيدة "أغنيّة البجع". 
ـ الكثف عن الفضاء الكرونوتوبي ودوره في تشكيل بناء زمكاني في هذه القصيدة .

ـ معرفة الطاقات التعبيريّة والدلالات الإيحائيّة الناتجة عن فضاء الكرونوتوب.

مدود الدوراسة:

هذه الدر اسـة تنحصر في قصيدة "أغنيّة البجع" المنشـورة في ديوان "للريح ذاكرة.. ولي"، باعتبار هـا نمونجـاً

رائعاً لقصائد ممدوح المقاومة.

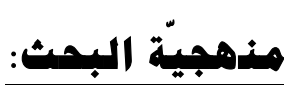

اعتمدنا في إنجاز هذه الدراسة على المنهج الوصفي التحليلي، إذ سنتناول بعض النمـاذج النصيّة لوصف الفضـاء

الكرونوتوبي في قصيدة "أغنيّة البجع"، وتحليل محتواها تحليلاً فنيّاً كاشفاً عن رؤية الثاعر التي بريد الإفضاء إليها.

\section{خلفية البمث:}

بالرغم من شيوع مصطلح "الكرنوتوب" في البحوث النقديّة إلّا أنّـا لم نعثر على دراسـة مستقلة تحمل هذا الإسم

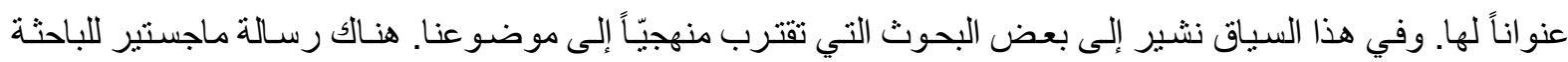

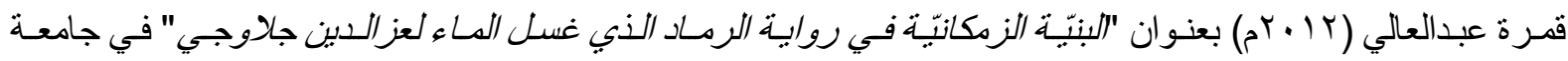

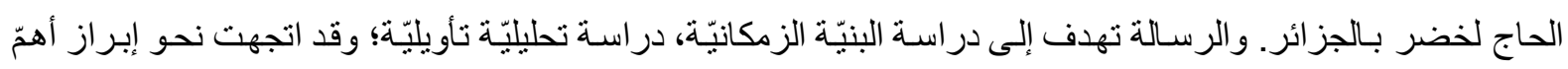

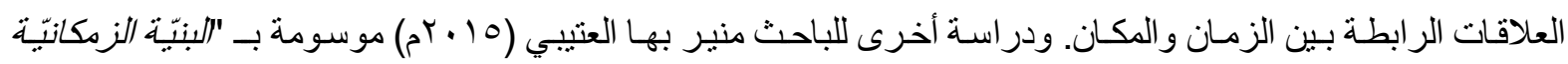

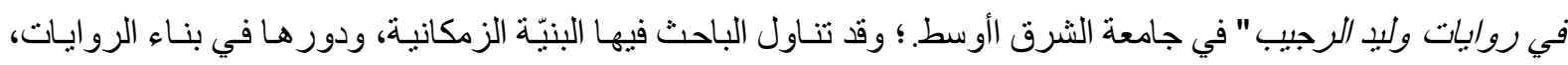
وذلك بالوقوف على تقنيات بناء الزمن التي وظّّها الكاتب في رواياته كالاستباق، والاسترجاع، وتسريع السرد وتعطيله،

مع ما يرتبط بذلك من حذف، وتلخيص، ووصف، ووققات مشهية، وبتجليلة طبيعة الأمكنة التي جعلها عالماً لرواياتها. ومسن الدر اسـات التـي تناولت شـعر ممـدوح عـدوان رسـالة ماجستير للباحث صـدام عـلاوي سـليمان الثــايب

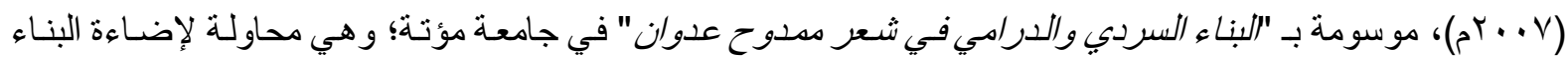

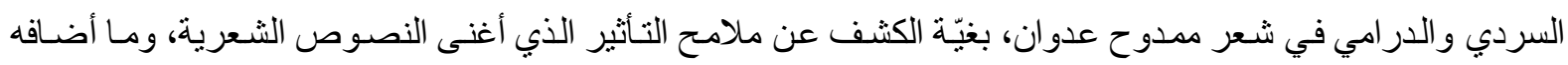

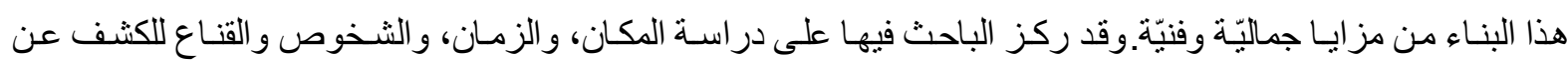

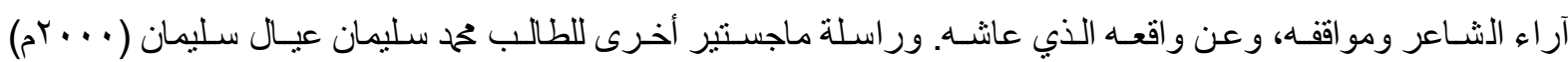

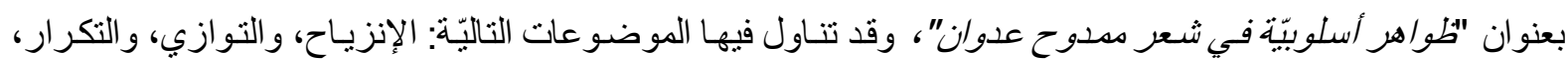

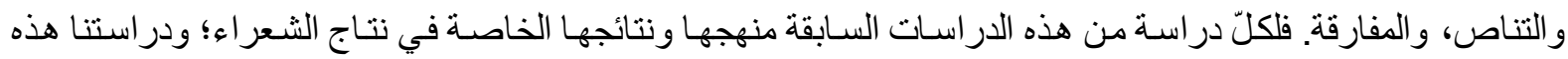

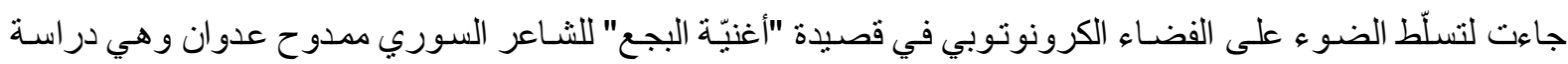
جديدة في هذا المجال.

\section{هياة الشهمر:}

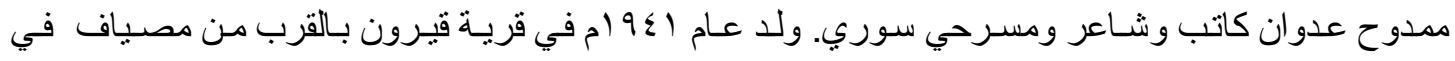

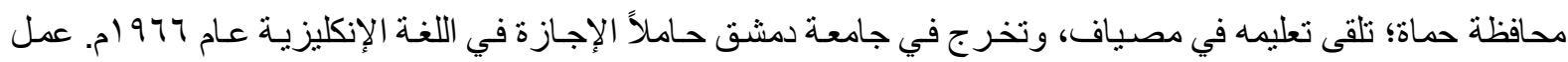
في مجال الصحافة السورية (جريدة الثورة) منذ عام ع 97 (م، وكتب العديد من المقالات في الصحف السورية و المجلات

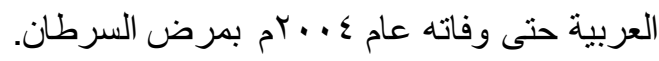




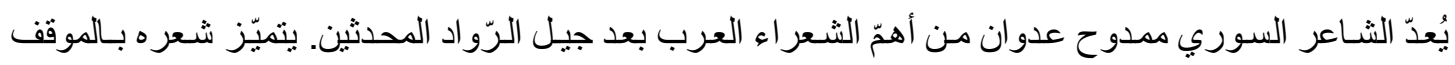

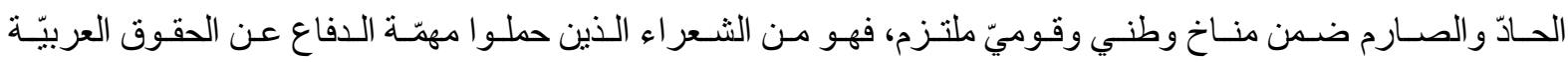

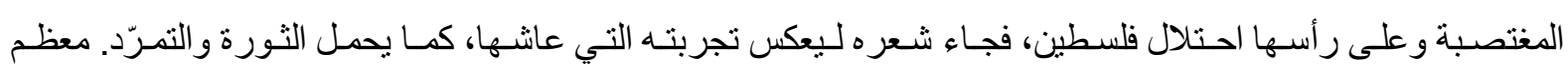

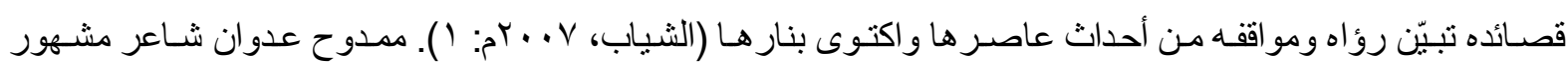

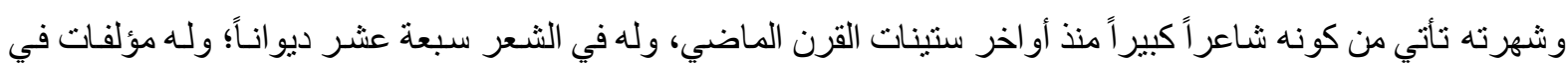

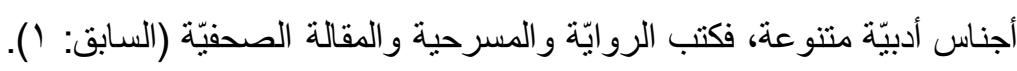

\section{قميدة " أغنيّة البجهع"}

مصطلح "أغنيّة البجع" هو تعبير يرمز إلى آخر محاولـة أو جهد أو إنجاز يُودّى قبل الوفاة أو الرحيل. فـالمؤدي

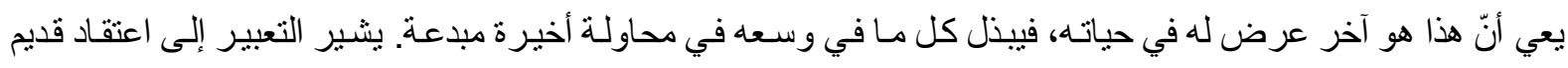

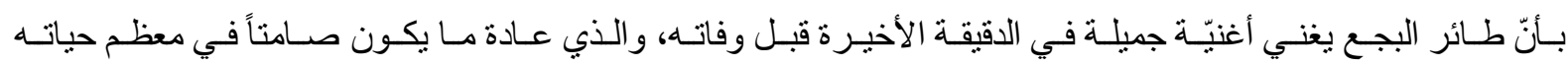

(www.marefa.org)

قصيدة "أغنيّة البجع" من أنــهر قصـائد ممدوح عدوان وأروعها؛ وتُعتبَر نداء أخير للأمـة العربيـة تجـاه القضيّة

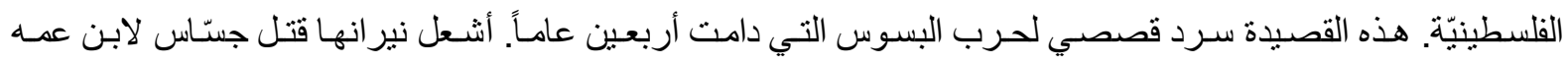
الفـارس المغوار و ائل بن ربيعـة الملقّب بكليب، وانبرى الزير سـالم (عدي بن ربيعـة) لأخذ تثأر أخيه المقتول غدر اً. لقد

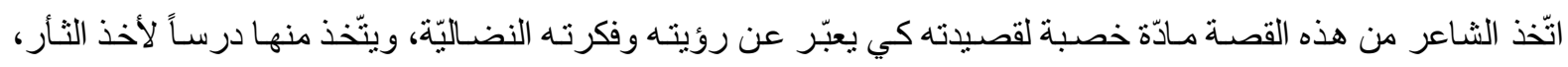

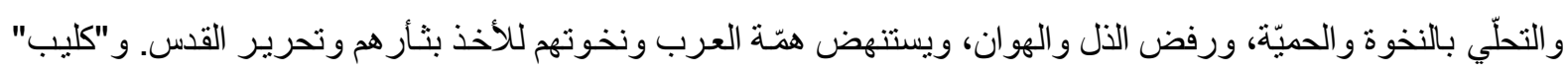
المقتول يرمز إلى الثعب الفلسطيني الذي أصبحت إر ادته وكرامته مستهذفة.

الفضاء

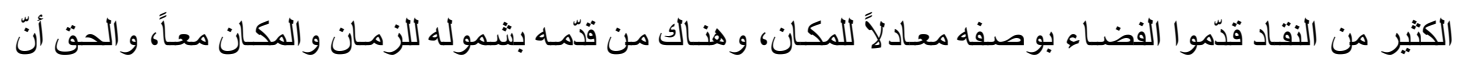

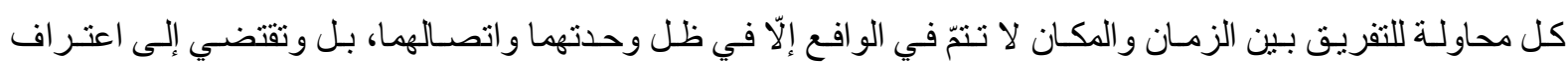

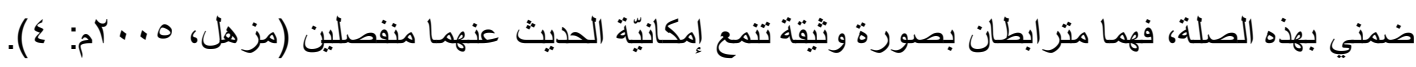
يشمل مصطلح الفضـاء ـ عند الكثير من البـاحثين ـ المكان و الزمـان، لأنّ علاقات الزمـان لا تمنح دلالاتها إلا

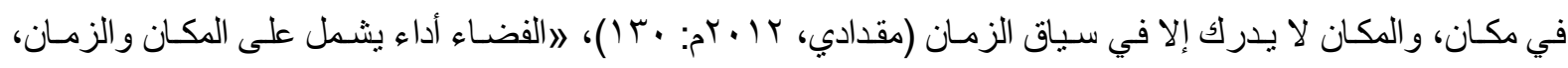

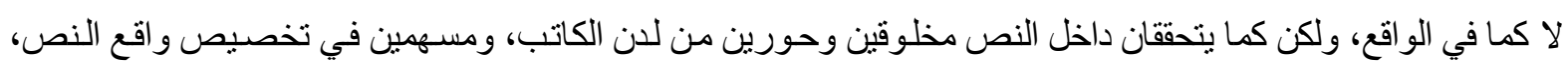

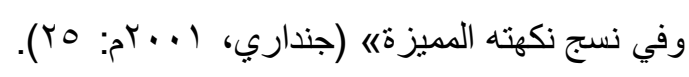

تجدر الإشـارة إلىى أنّ علاقـة الزمـان بالمكـان غير مقيدة لابقانون سـوى قـانون الجمـال كمـا أنّ كليهــا لبس لـهـ

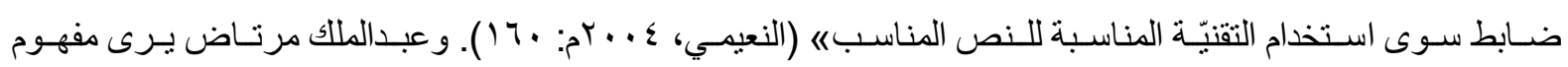

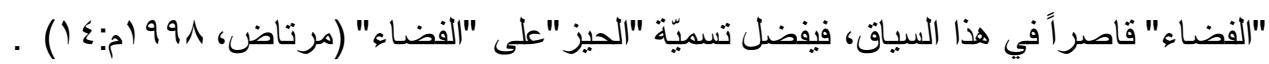


الدكرونوتوب

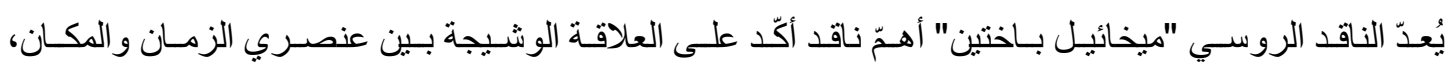

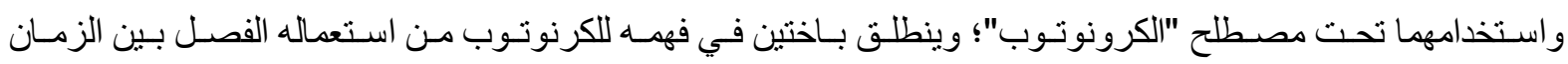

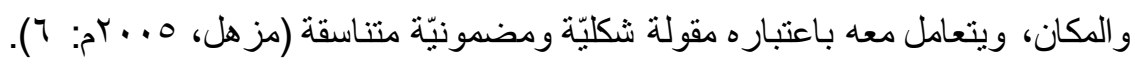

الكرونوتوب يعتمد على إدمـاج الزمـان في المكـان لتشكيل فضـاء واحد يسمّى بالفضـاء الزمكاني؛ ويتّسم هذا

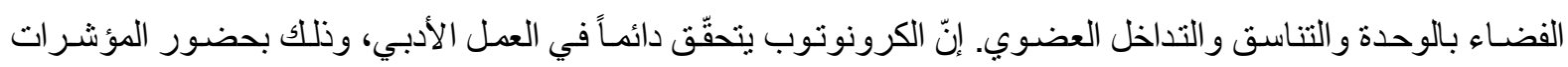

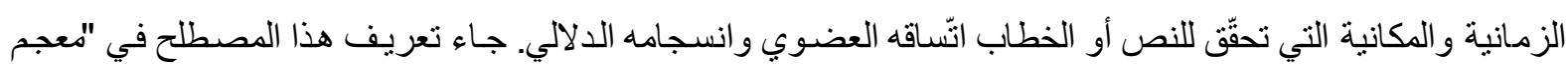

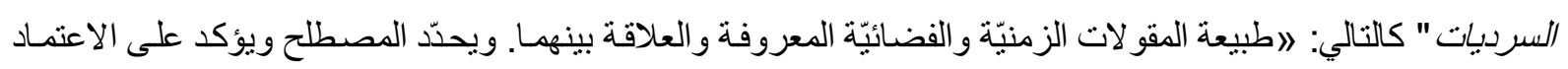

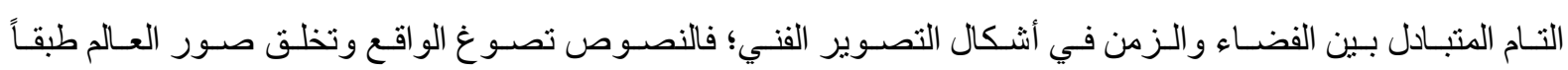

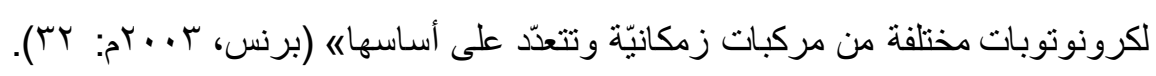
عرض التفاصيل الدقيقية للطبيعة المكانيّة والزمانيّة في قصيدة "أغنيّة البجع" أصبحت جز عاً أساسيّاً من البنـاء

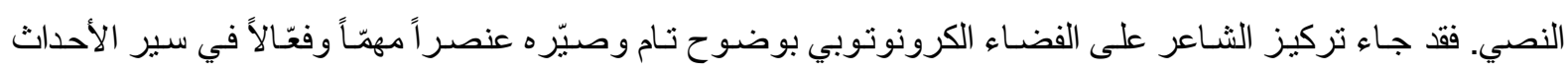
وجعله المحفز الرئيس للسرد من أجل رسم صورة كاملة للأحداث.

\section{نانㄴos}

حركة الزمن لا يمكن لها أن تنفصل على أيّ حسالٍ عن فضـاء النص ككل، وذلك لأنّ حركة الفضـاء ليست نتاجـاً

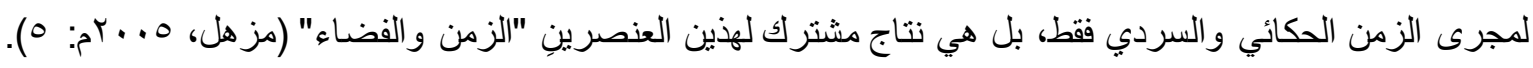
للزمن أثر كبير في بنـاء الأجناس الأدبيـة؛ ونلك لأنّ الزمن الأدبي زمن التجـارب والانفعـالات، وزمن الحالـة

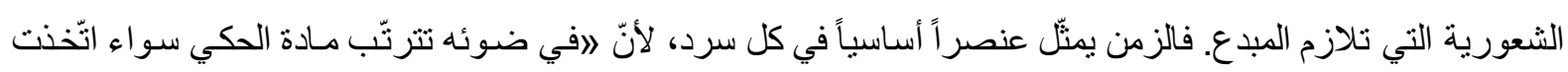

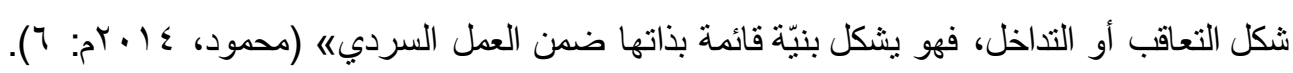
الزمن في مفهومه الأدبي آليّة مهمّة لها أبعاد وظيفيّة وجمالبّة؛؛ فهو يشكّل أداة فنيّة في العمق الشعري، يدوّن بها

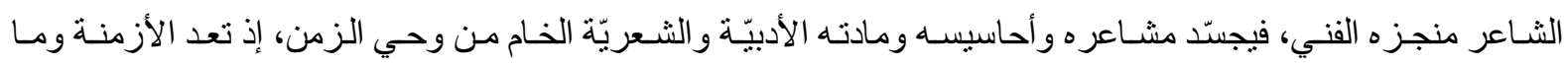

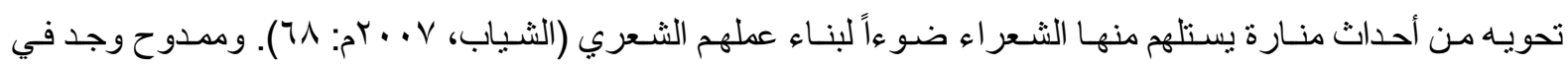
الزمن مادّة خصبة لبناء نصوصه الشعرية لتجسيد مشاعره وأحاسيسه؛ ففي قصيدة "أغنيّة البجع" يُعتبَر الزمن آليّة جماليّة ذات دلالات وظيفيّة لتشكيل العمق الشعري.

رسم الشاعر لوحة تسجيلية متكاملة لوقائع ماديّة حسيّة ووجدانيّة تشكل حالة من التر ابطو التماسك بين حاضره المؤلم و الماضي الذي تغنّى به بكل شوق واعتزاز. فالتنـاوب بين الماضي والحاضر في هذا النص ينّم عن تعلّق الثـاعر

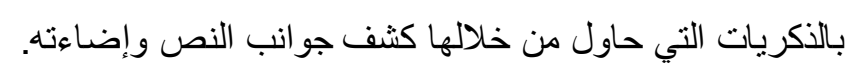

هذه القصيدة لم تكن مجرد أداة لغويّة تنقل لنـا تفاصيل زمنيّة ماضية فحسب بل تشكّل بنيّة هندسيّة تعيد هيكليّة

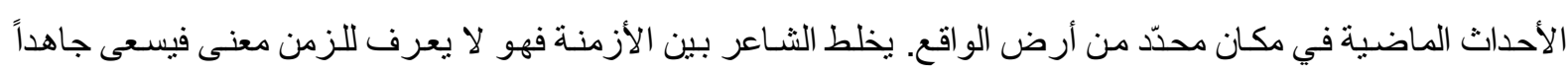
لتحقيق هدفه ومبتغاهوهو أخذ الثأر عاجلاً غير آجلٍ: 


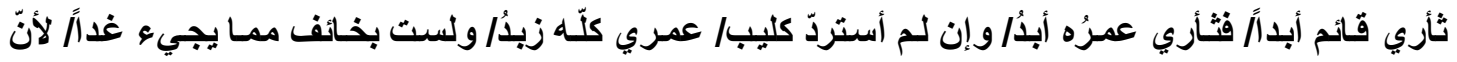

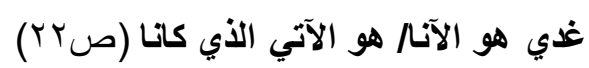

فقد كرّس جهده وحياته على الظفر بثأر أخيه، وقد خصّص لـه زمنـاً طويلاً (عمره أبدُ)، فيعتقد بالثأر بستطيع أن

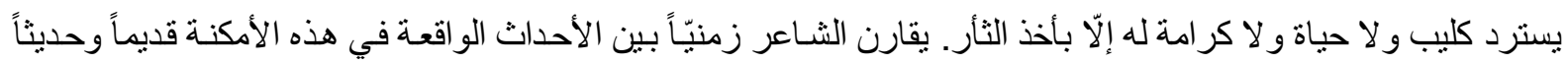

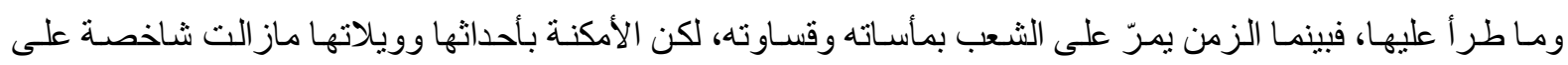

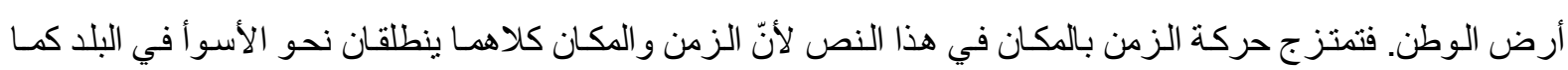

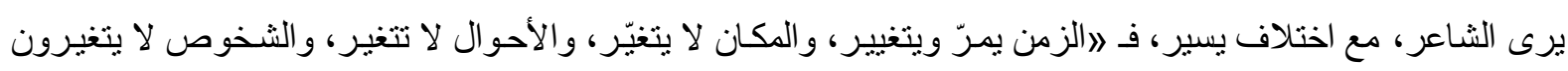

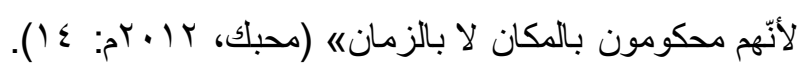

الإسترجزاع

الاسترجاع يعود بحركة السـرد إلى الوراء، فيستعيد الماضـي بمـا يخدم اللحظة الحاضـرة. كل عودة للماضـي

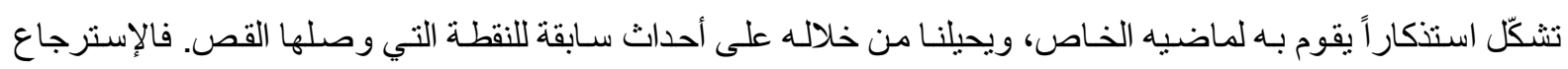

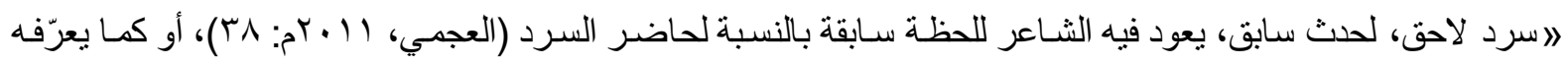

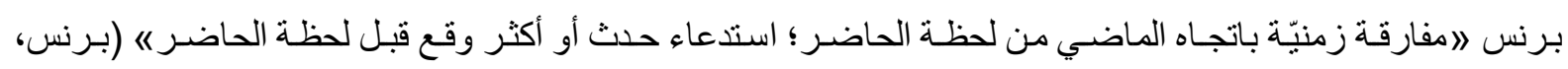

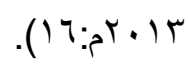

ومددوح يحساول إسترجاع الماضـي ونفث الحيـاة في تفاصيله ليشكل وجوداً متخيلاً يتفاعل في مجر اه وعي

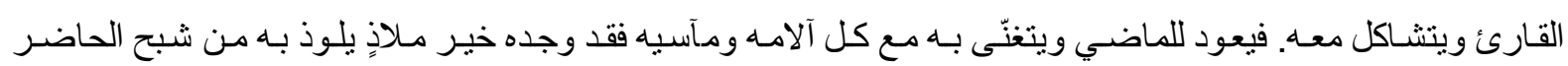
وكوارثه التي أفقدت البلاد معالمها وتر اثها:

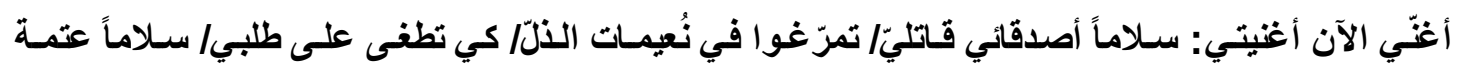

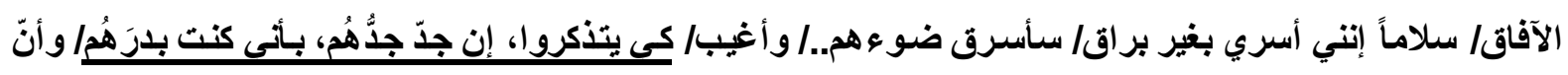

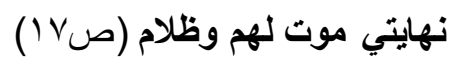

ففي هذا المقبوس يعود الثـاعر إلى ماضيّه ويذكر قومسه بمكانته السـاميّة بينهم فقد كـان لهم سـابقاً بمثابـة البدر

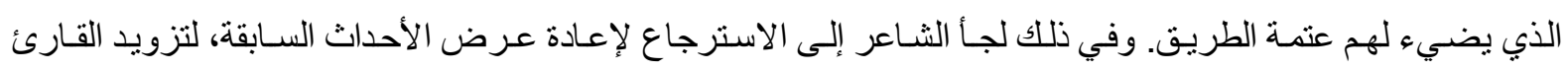

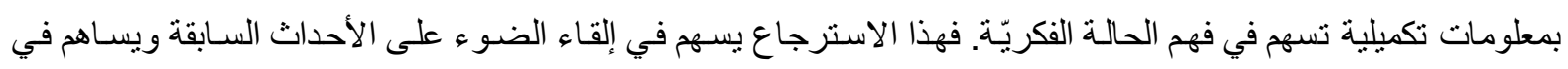
إضـاءة النص.

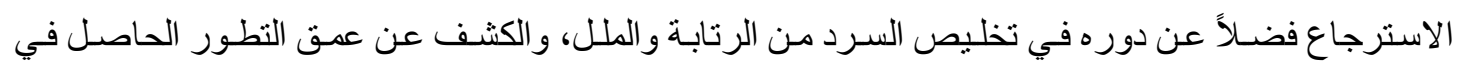
الحنث، يقول بتمكين المتلقي من رؤيـة الآتي في ظل معطيات الحاضر و استرجاع الماضي، كي تكون رؤيته واضحة

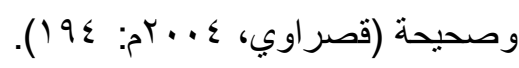

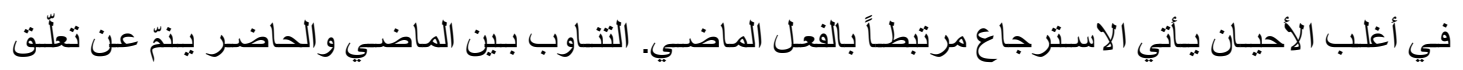

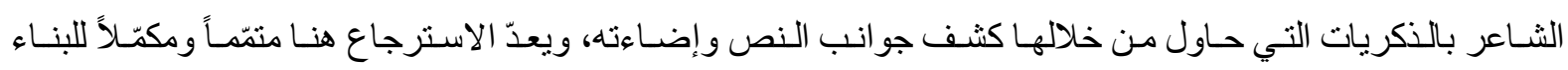
الزمني. التركيز على الماضي يكثف عن نعلّق الشاعر بالذكريات التي حاول من خلالها إضـاءة جوانب النص. 
لقد كان مدور مستغرقاً في الماضي، واستغر اقه كان إيجابياً حين أصبح الماضي محفّز اً ومحرّكاً لروح جديدة،

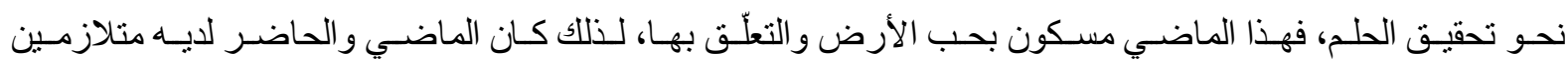

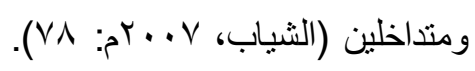

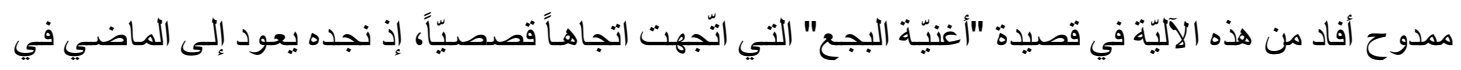
لحظات سرديّة معينة، ويفيد من هذه التقنيّة في تشكيل نصده:

سأنزل عن صليبي كي أصارحكم:/ أريد كليب/ وثأر كليبَ لا يخبو مع الأيام/ بل يتعثّق الثأر (ص.r)

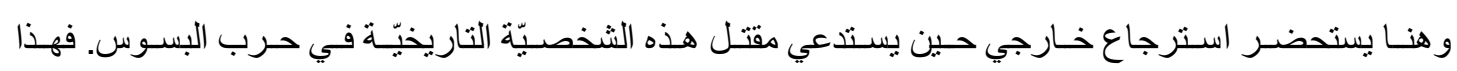

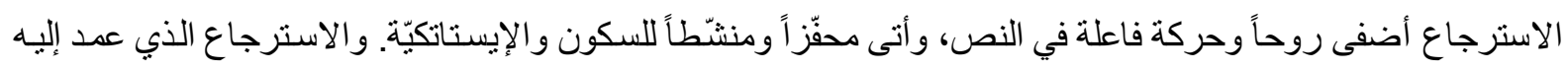

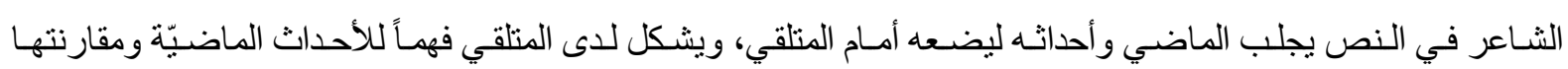
بالأحداث الواقعة في الحاضر و المستقبل بعد ذلك.

$\underline{|l| l|l| l \mid l}$

الإستباق أو القفز إلى الأمام هو كل مقطع حكائي يروي حدثاً سـابقاً عن أو انه، أو يمكن توقّع حدوثـه؛ ويقتضي

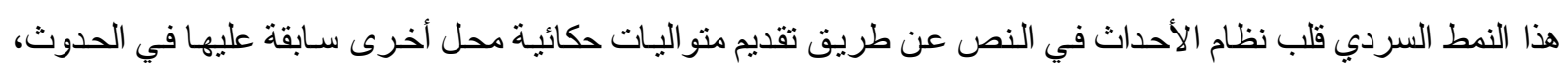

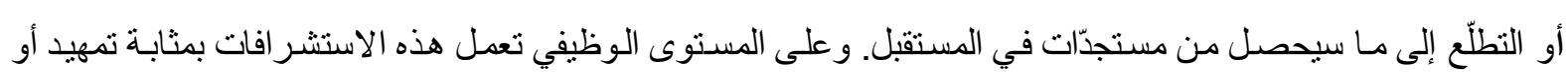

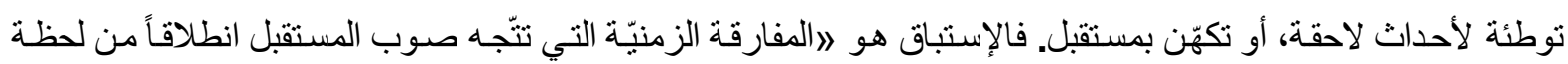

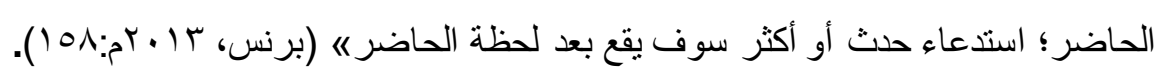

الاستباق ينطلق نحو المستقبل، ويأتي للتطلّع إلى الأمام، ومحاولة استكثـاف المجهول. يبدأ الثـاعر بـالتنبوُ بمـا سيحدث لاحقاً، حيث يستخدم الثـاعر في رؤيته المستقبليّة للأشياء أو مـا ستؤول إليه الأحداث، (سين) التسويف، وكلمـة (سوف) للالالة على الزمن القادم المستقبلي:

أبصر مـا خشيت ومـا عرفت كعالمٍ بالغيب:/ رجلاً يهرمون بـلا سنين/ وعـار هم قد حط مرتاحساً محلّ الثيب|

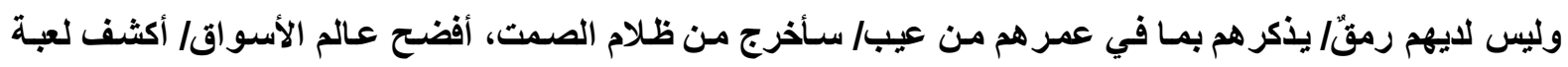

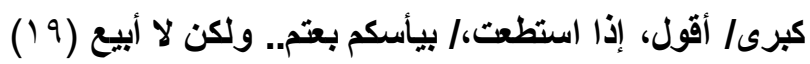
الاستشـر اف هنـا استشر اف تشـاؤمي، حاول من خلالهـ الثـاعر استباق الحسث لاسـتظهار صورة الحزن التـي طغت على النص.

\section{الترتيب الكوونهولوجي}

الكرونولوجيا تعني تقسيم الزمن إلى فترات، كمـا تعني تعيين التواريخ الدقيقة للأحداث وترتيبها وفقاً لتسلسلها

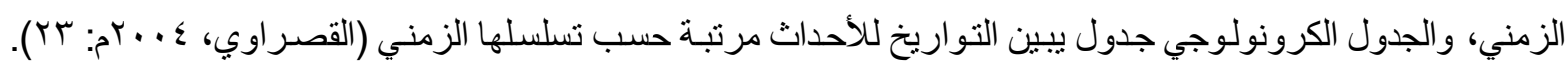
وجـاء في "قـاموس السـرديات" تحت هذا المصطلح، أنّه لاتنظيم المو وقف والأحداث وفقاً لترتيب حدوثها. إنّ المنطوق

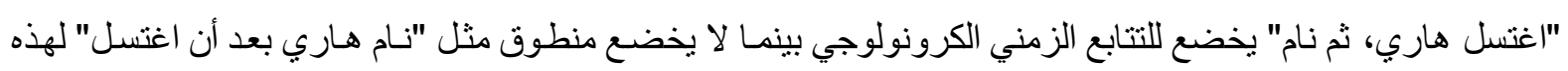

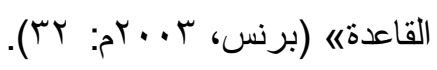




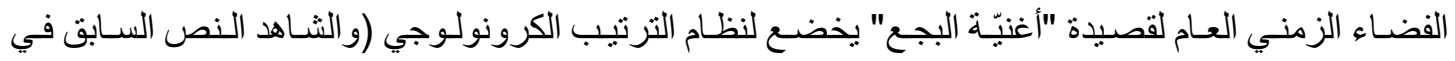

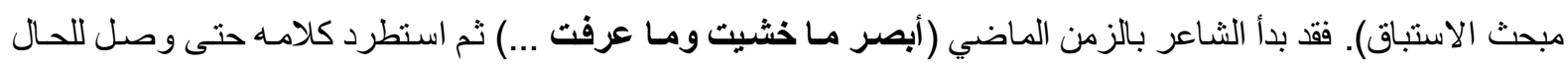
(وعار هم قد حط مرتاحاً محلّ الثيب/ وليس لايهم رمقُّا يذكرهم بمـا في عمرهم من عيب) وختامـاً عبّر عن المستقبل بالسين (سأخرج من ظلام الصمت، أفضح عالم الأسواق/ أكثف لعبة كبرى/ أقول، إذا استطع،/ بئأسكم بعتم.. ولكن لا لا أبيع). فهذا الترتيب الزمني للأحداث يطلق عليه الكرونولوجيا.

ن(إ)

يحتلّ المكان مسـاحة كبيرة في حيـاة الإنسان؛ فهو يبدأ في رحم الأم بيولوجيـا، وينتهي في فبر يحمل حصيلة

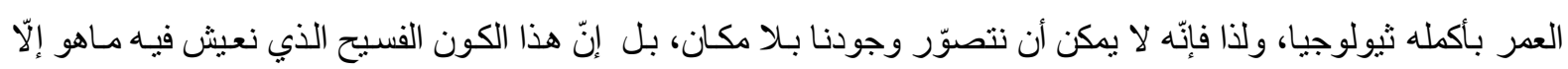

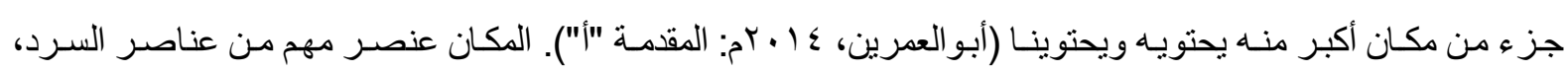

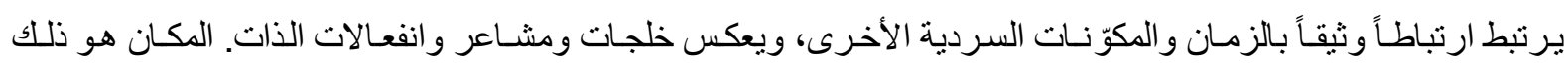

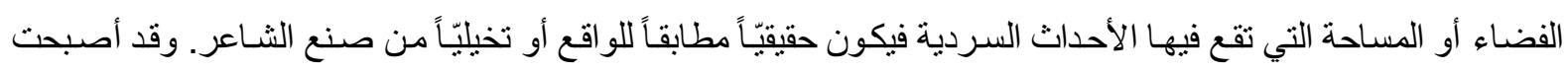
ذاكرة المكان مارسة وجوديّة تسعى لنرسيخ هويّة الإنسان بوطنه.

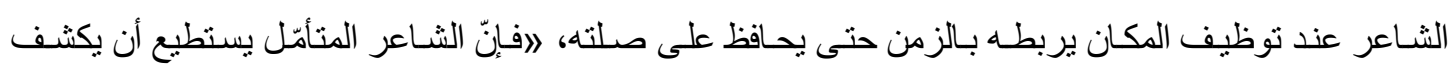

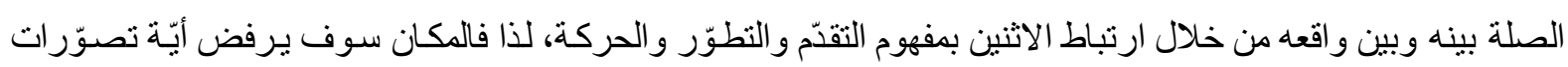

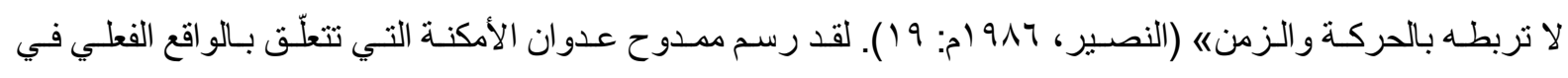
معظم قصـائده، فنجده ينظر إلى المكان بنظرة مختلفة، فلم يعد المكان هو مصدر الطمأنيّة الإنسـانيّة؛ فمن يتجرّ ع الظلم

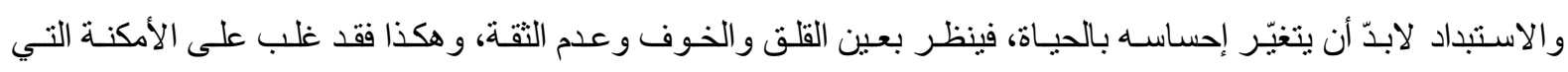

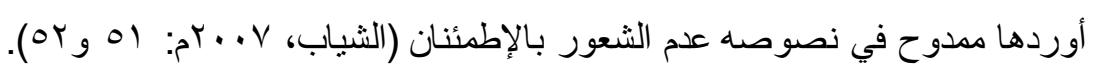

إنّ المكان في كثير من الأحيان، يحمل دلالات رمزيـة، فلالنهر، والبحر، والصحر اء، والسجن، والبيت، وغيرهـا

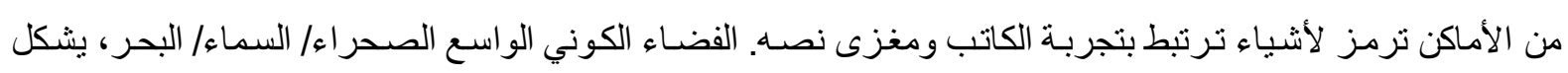

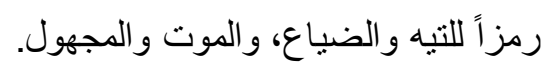

\section{ثنانيّة الانفتاه والانغلاق:}

تنقسم الأمكنة في هذه القصيدة إلى أمكنة "مفتوحة" وأخرى "مغلقة"، وهذه الأمكنة شغلت حيزاً واسعاً في فضـا

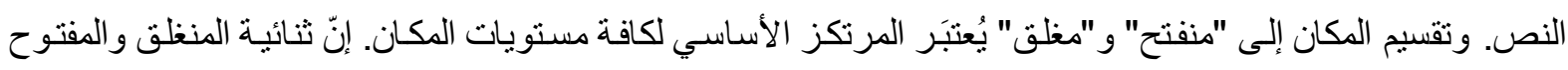

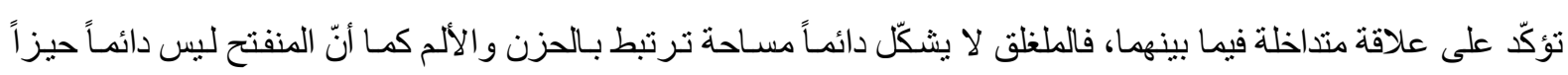

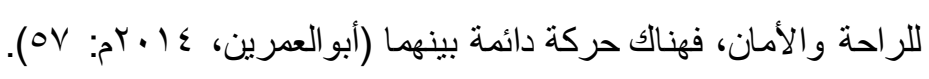

\section{إلمان المفتوح:}

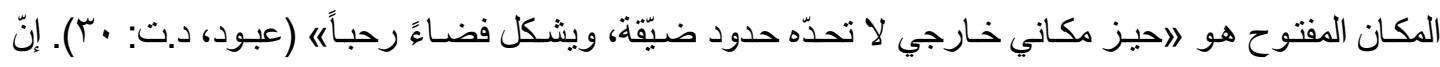

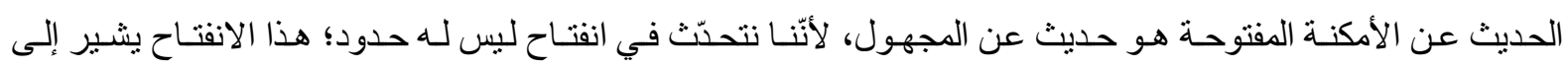

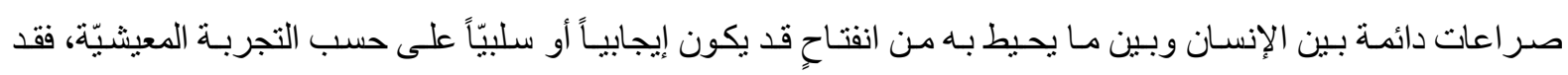

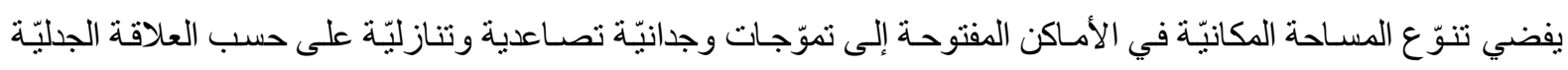

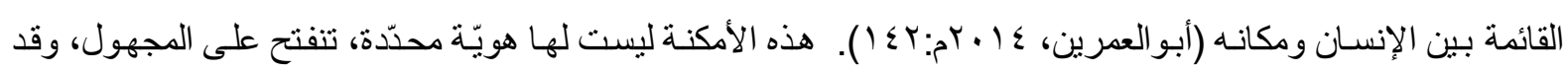


يكون لها بداية في مخيلـة المبدع، لكن ليس لها نهايـة في مخيلة المنلقي (السـابق: 9ه). تنقسم الأمكنة المفتوحة إلى فضـاء بلا حدود وفضاء محدود.

فضاء بلا مدود

هذه الأمكنة المفتوحة لاتحدّها حدود، فهي وسيعة متر اميّة الأطر اف و إن وجد لهـا حدود في الو اقع فهي غير

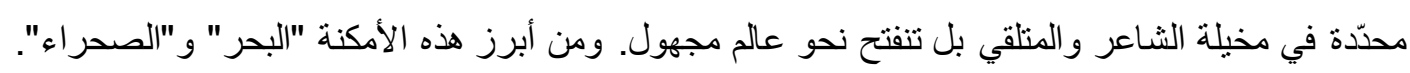

البحر مفتوح بامتداده الثاسـع وانفتاحسه المجهول. و لا يخفى أنّ الخـوف والخطـر في سياق القصـيدة البحريـة

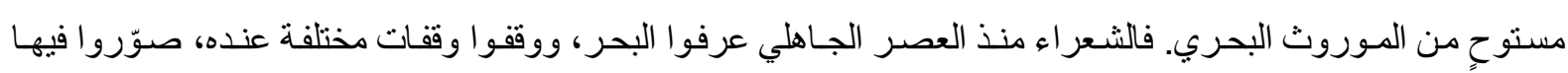

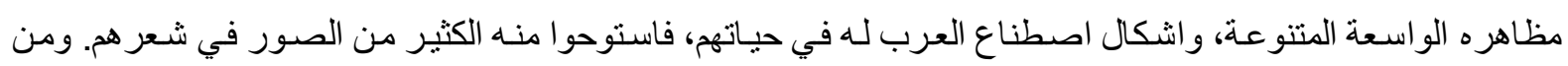

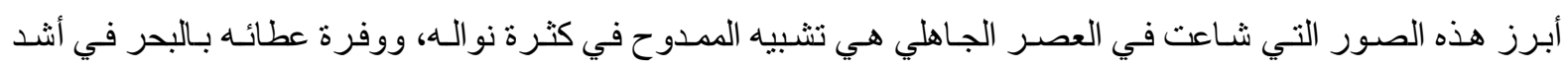

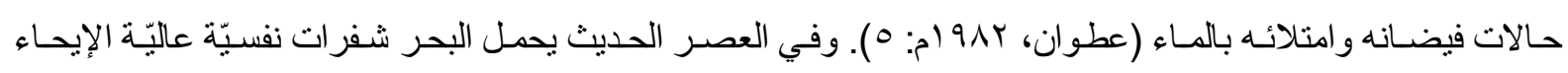

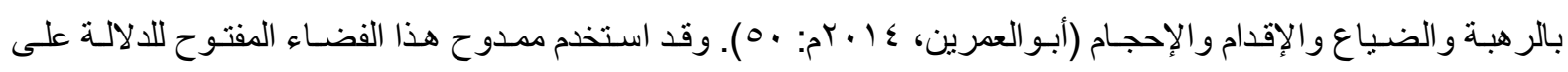

الخوف و الرهبة:

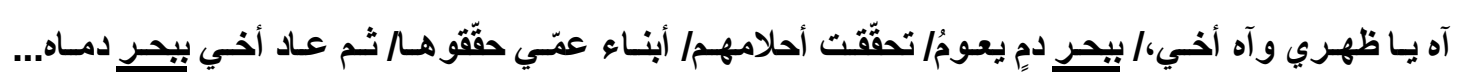

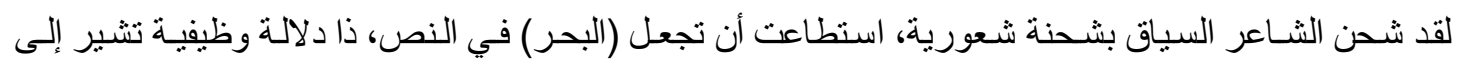

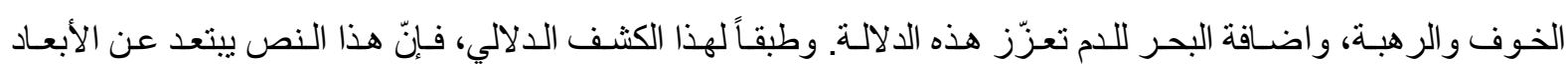

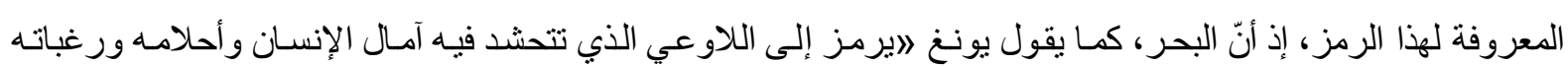

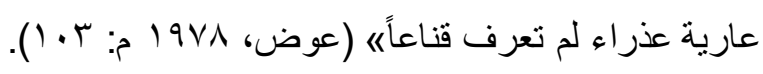

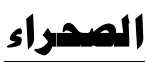

الصحر اء تحمل الكثير من السمات العربيّة، إذ هي منبع الثعر و الثقافة قديماً، وهي أصل الشـاعر، تختزل في

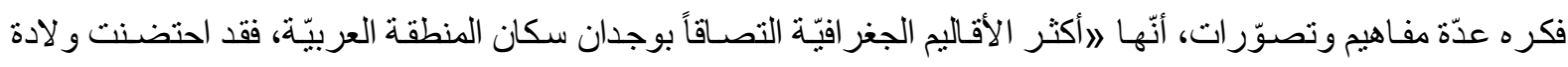

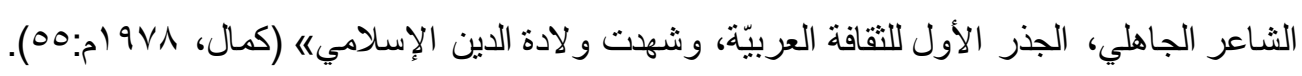
تشكّل الصحر اء مكاناً واسعاً فهي ببعدها الثاسع تمثّل حساجز يفصل الأقطسار بعضهـا عن بعض، و لابدّ للذي

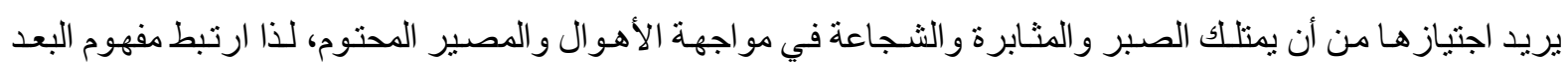

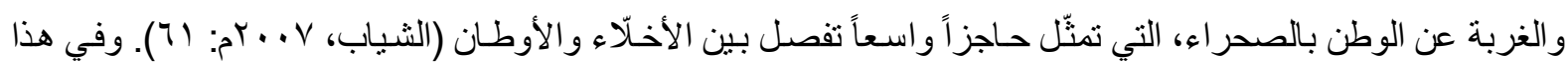

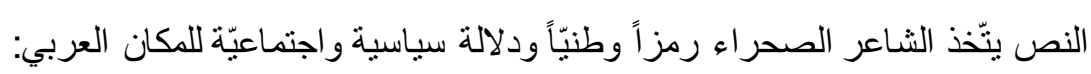

أنا البحّار جاء إلى صحار اكم/وقد أحرقتم سفنه/ أتى ليرى لليكم عمره/ لكنّكم أهدرتُم زمنه (صبr) فهنـا تمثّل الصـحر اء أرض الوطن، واستخدم الثـاعر في هذا السياق تعـابير تشي بـالحزن و التوتر كـ "أحرقتتم سفنه"، و "أهدرنت زمنه". إنّ الصحر اء بوحشتها لاقد تومئ إلى فضـاء نفسي يميل إلى الحزن و الوحدة) (أبو العمرين، (0. 
فظفاء مصدود:

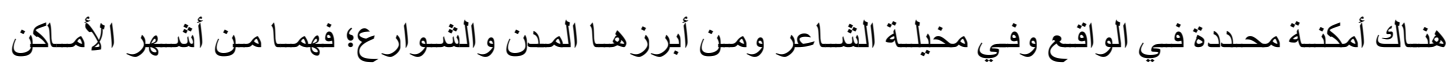
المفتوحة المحدّدة بفضائها الواسع و اللامتتاهي من الأحلام و الآمال و التي لا يقّبّها حكم أو تقليد.

: إلمدن

تُعدّ المدينة في الشعر العربي المعاصر من أهم الإضـاءات التي تلفت أبصـار الشعراء، وبمـا أنّ المدينـة مركزٌ هـامٌ

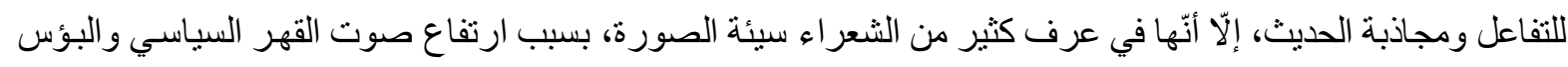

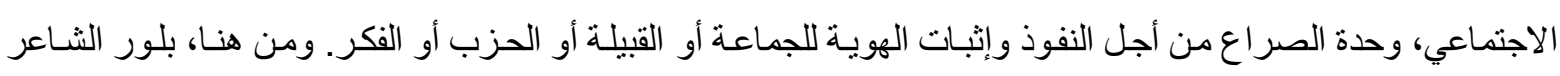

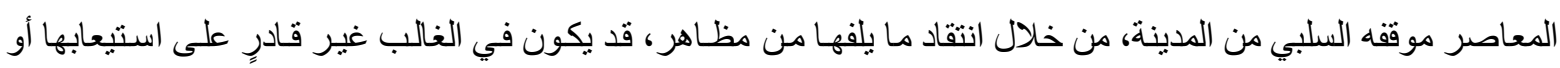

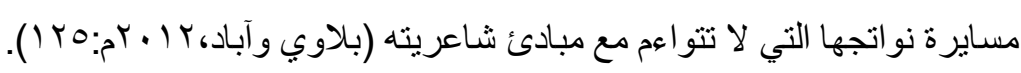

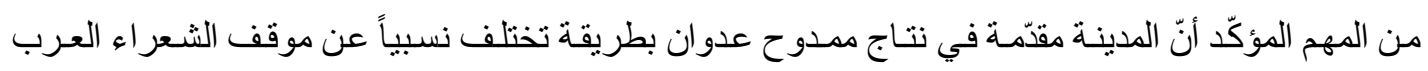

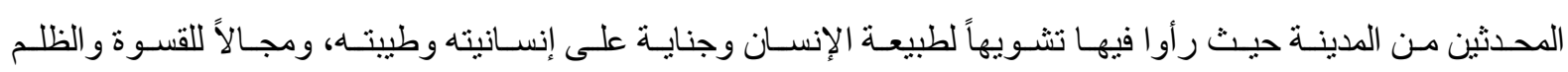

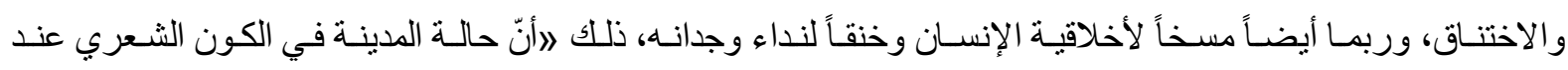
الثـاعر هي جزء من مناخ التراجيديا المخيّمة على الوجود، وهي نفسها من وقود المأسـاة وليست بالضبط مسبّبة المأسـاةها

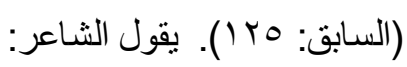

ويبقى بينتا دَين عريق ليس في الدنيا له ثمنُ:/ ستبقى بيتنا المدنُ/ هي المدن التي جاءت إلى أهلي/ وصـارت من أريج البيت (صه广)

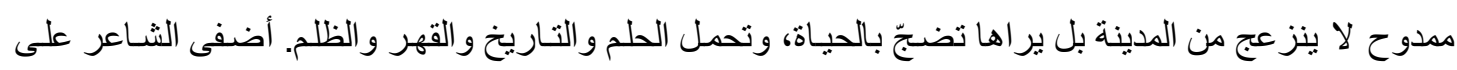

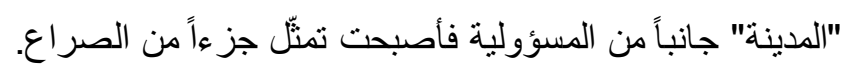

\section{المدن الففلسطينية}

احتضن الثـاعر واقع الوطن العربي، احتضن مدنـه وبلدانه وقراه الفقيرة واحيـاءه البائسـة التي يعثـش فيهـا

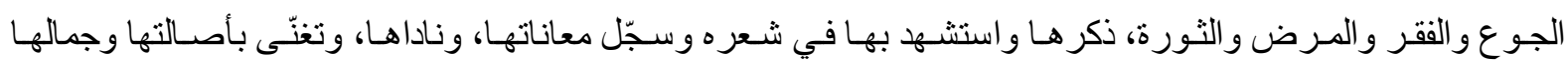

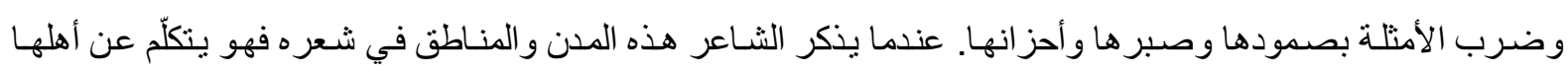

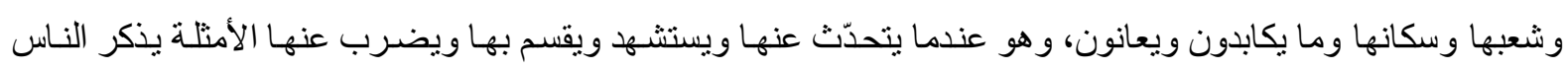

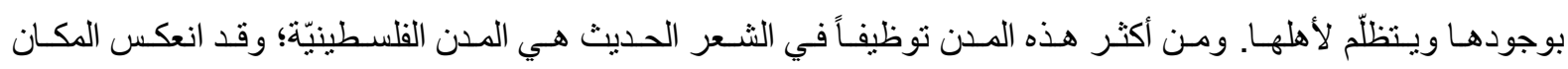

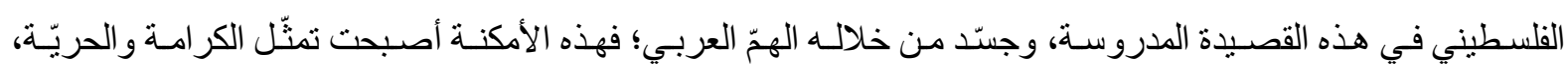
وترمز للهويّة القوميّة والدينيّة:

يصبح بيتنا في السرّ خارطة/ به أولادنا مدنُ/ هنا حيفا.// هنا يافا.// هنا بيسان (صצr) و الثـاعر من خـلال استدعائه لهذه المدن استطاع أن يجعل القارئ يتنفّس معه الألم والقهر النفسي الذب يعيشهـ ضمن مكانه الخاص.

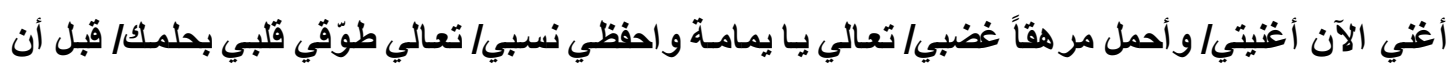

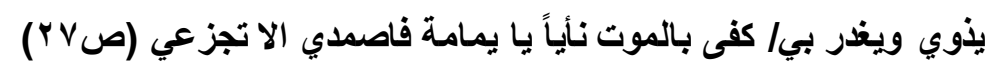
$-\Lambda$. - 


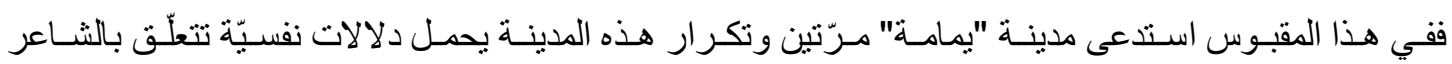
ونفسيته، وما يخالجها من عشق وحنين إلى هذه الأمكنة.

ع|sm|

الشـارع في شعر ممدوح من الأمكنة التي تبعث الخوف و الرهبة و الملل، فقد أصبح سـاحة معركة وصر اع؛ وقد

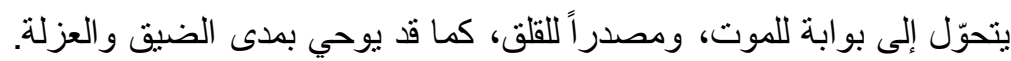

كيف أقول للمدن التي صارت بنيُ:/ تر اجعي.. لم ييق في دنياي بعدُ مكان/ وأخرج من هموم البيت والمنياع/

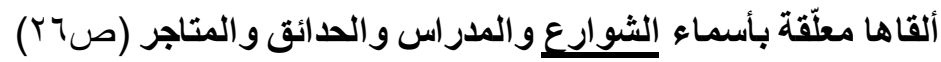

فالشار ع مكان مفتوح و هو مسار وشريان للمدينة، ومصب الليل و النهار وتجلياتهمـا. في هذا السياق "الشوارع"

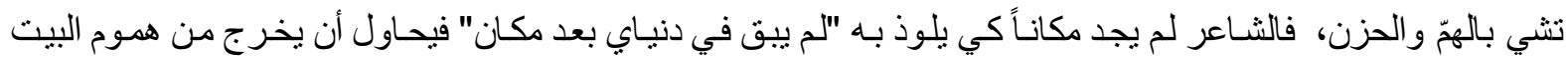

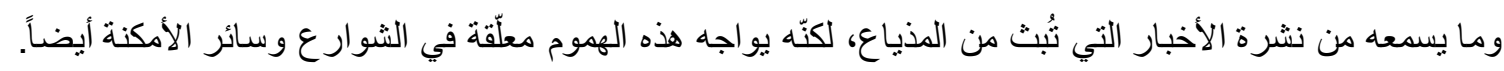

\section{إنان}

فضاء هذه الأمكنة يكثف عن صـر اعات قائمسة بين هذه الأمكنة وبين الإنسـان، فمنها مـا يحقّق السعادة والألفة

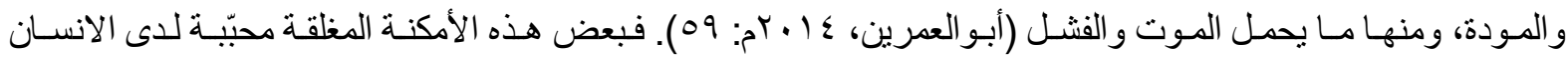
كالبيت و المقاهي مثلاً فيشعر بالر احة و الألفة فيها، وبعضها تحمل القلق و العدميّة كالقبر. المكان المغلق ينقسم إلى قسمين؛

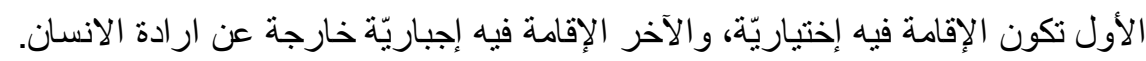
إلاقامـة الإختياريّة كفضـاء البيوت، و الغرف، والمقاهي. يختار هـا الثـاعر طواعيّة للإقامـة وقد تكون هذه الأمكنة محبّبـة لإى الثاعر يرناح لها.

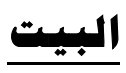

هذا المكان المحدّد يختـاره الانسـان طو عـاً للعبش فيه، فلاشك ستكون دلالاتـه إيجابيّة ومحبّبة حيث يجد الإنسـان الراحـة

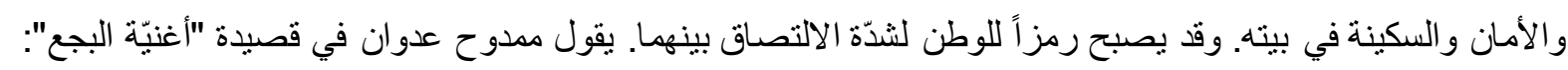

$$
\text { يصبح بيتنا في السرّ خارطة/ به أولادنا مدن (صجr) }
$$

و أيضاً يقول: وييقى بيتنا ََين عريق ليس في الدنيا لـه ثمنُ:/ ستبقى بينـا المدنُ/ هي المدن التي جاءت إلى

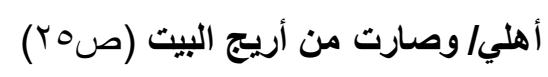

انتّذ الثـاعر هذا المكان ملاذاً للحريّة والدفه و الاستقر ار. يعتبره دَين عريق لا يضـاهيه مكان آخر في الدنبا، فهو يمثّل الوطن والاصالة. وقد يأخذ هذا المكان دلالة متناقضة: تراجعي.. لم ييق في دنياي بعُ مكان/ وأخرج من هموم البيت و المذياع (صَr) فالبيت هنا يبعث الهمّ والحزن لانغلاقه فيحاول الثاعر الخروج منه باحثًاً عن راحة البال.

(1)

المدارس من الأمكنة المغلقة التي يختار هـا الإنسـان طوعاً غير مر غِ ومن شـأنها أن تبعث الأمل والمثنابرة في

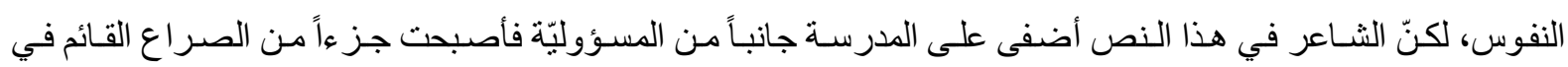




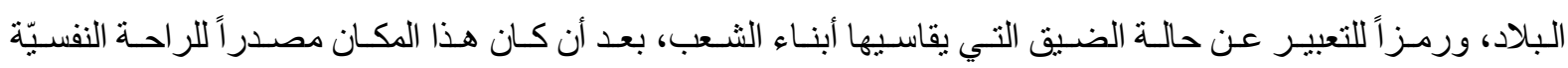
و الطمأنينّة، يبعث الأمل في النفوس، ويقدّم الخير للناس:

كيف أقول للمدن التي صارت بنيُ:/ تراجعي.. لم يبق في دنياي بعُ مكان/ وأخرج من هموم البيت والمذياع/

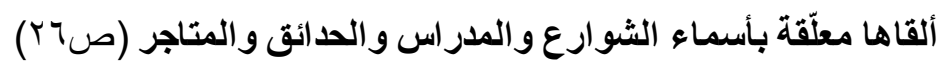

المكان/ المدرسة في هذا السياق فقد لونه وطعمه ور ائحته ورسـالته، وأصبح مرنعاً للحزن فهـا أن يخرج الثـاعر

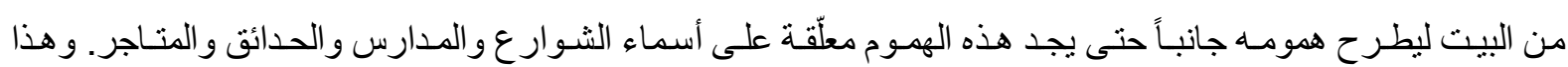
الأمر يدلّ على عموميّة الحزن وشيوعه على نطاق واسع في البلاد حنى يراه الثـاعر منمثّلا في كل معالم البلد.

\section{إقامة إبمباريةّ:}

هذا النوع من المكان يمثّل الفضاء الذي يحوي حدوداً مكانيّة، وقد يكون ضيّقاً مغلقاً. هذا المكان المغلق/ الضيق

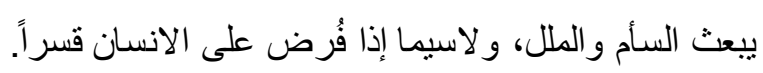

السجن والنزنزانة:

السجن من أكثر الأماكن انغلاقاً مكانيّاً ونفسياً، ويثير القهر القسري والعتمـة. فهذا المكان المغلق يدلّ على مأسـاة

الشعب و اضطهادهم.

سئمت براعتي من هول هذا الجرم/ صرت أغصّ بالمـاء/ الذي يطفو عليه الذلّ/ إن حيـاد سجني مفعمٌ بالذنب

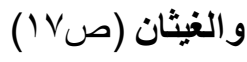

فالشاعر يصف حالته المترديّة بهذه الأوصـاف "سئمت براءتي" و "صرت أغصّ بالمـاء"، ثم هذا السجن رغم

انغلاقه فقد يحيط به الذنب والغيثان. فلصورة التي يرسمها الثاعر صورة مزعجة وحالكة تثي بالقهر والحزن.

أمّا الزنزانة فقد ترمز أحياناً إلى الدأب والسعي لكل من ركب مركب الجهاد والمقاومة والدفاع عن كرامة الوطن:

أقول لعالم يبدو من الزنزانة:/ اسمغن/ولا تسمع فيح اليأس (ص9 1)

فهذا العـالم رغم ضـيقه وانغلاقـه حسب رؤيسة الثـاعر (حيث يبدو لـه من زنزانـة)، لا يستطيع أن يقهر الثـاعر ويثنـي ارادته.

القبر

القبر يشكل مكانـاً ضيّقاً مغلقاً، وهو بمثابـة مجمع ومثنوى أخير ، كما يمتـاز بالظلمـة و العتمـة، فقي هذا المكـان

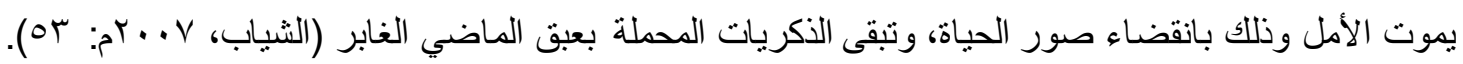

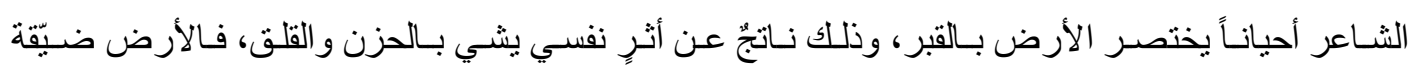
كالقبر. وكثرة المقابر تدل على كثرة الججازر وتردّي الأحوال والظروف في البلاد. يقول ممدوح: هم صنعو النا يأساً/ لكي يضحي لهم ستراً/ وكي يضحى لنـا غدراً/ وهم صنعوه كي يسترسلوا في اليأس/ ثم

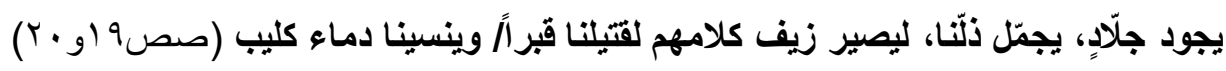

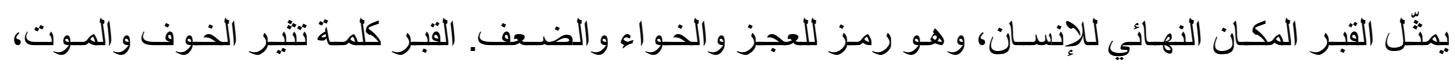




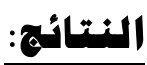

- ممدوح عدوان في قصيدة "أغنيّة البجع" للتعبير عن أفكـاره ورؤاه، استخدم عناصـر سرديّة تشـحن النص بطاقـات

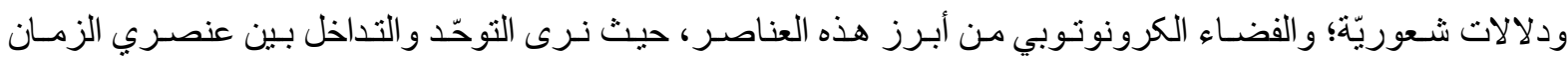
و المكان و واضحاً جليّاً.

ـ وجد الثـاعر في الزمن مادّة خصدبة لبنـاء نصوصسه الثـعرية لتجسيد مشـاعره وأحاسيسه؛ ففي قصيدة "أغنيّة البجعع" يُعتبرَ الزمن آليّة جماليّة ذات دلالات وظيفيّة لتشكيل العمق الشعري. ـ ـ التناوب بين الماضي و الحاضر في هذا النص ينمّ عن تعلّق الثـاعر بالذكريات التي حساول من خلالها كثف جوانب

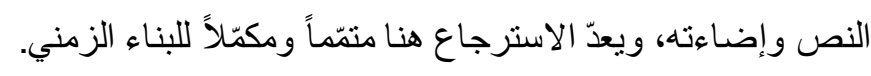
ـ البيئة المكانيّة تشكل ر افداً خصباً من رو افد الصورة في النص العدواني. و الفحص النقدي في هذه القصيدة يكشف عن

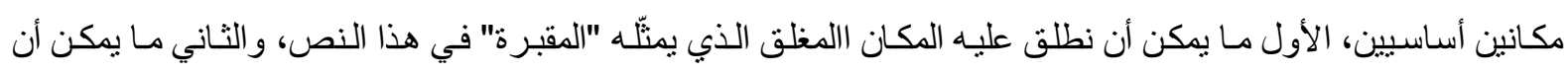
نسمّيه المكان المفتوح الذي يمثّله "البحر". ـ الكثير من الأماكن المفتوحة كالبحر و الصحر اءو والمدينـة والثـارع، والأمـاكن المغلقة كالبيت والمدرسة و السجن و القبر تحمل في جسد النص دلالات رمزيّة تكثف عن رؤية الثاعر التي يريد الإفضاء إليها من خلال السرد.

المادر والمراجع:

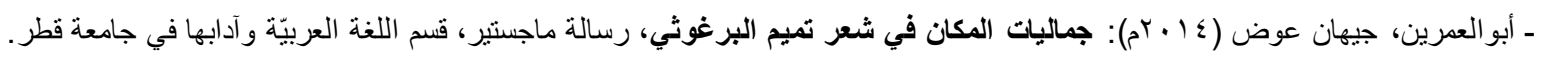

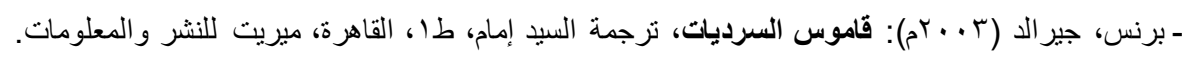

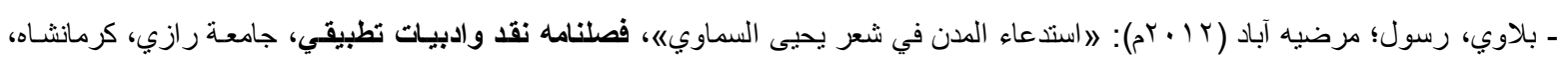

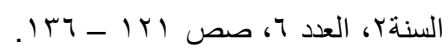

- جنداري، إير اهيم ( ( . . rم): الفضاء الروائي عند جبرا إبراهيم جبرا، طا، بغداد، دار الثؤون الثقافيّة العامة.

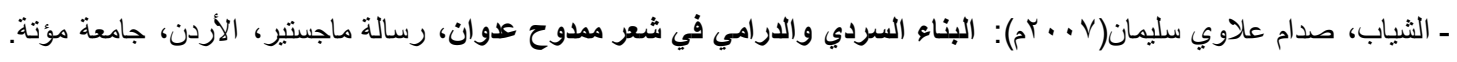
- عبود، أوريدة (د.ت): المكان في القصة القصيرة الجزائرية الثوريّة، رسالة ماجستير، كليّة الآداب و اللغات، الجز ائر.

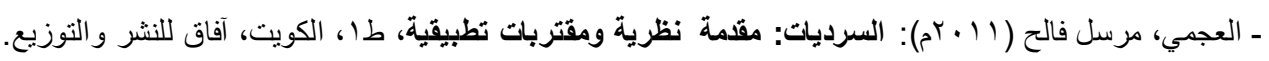

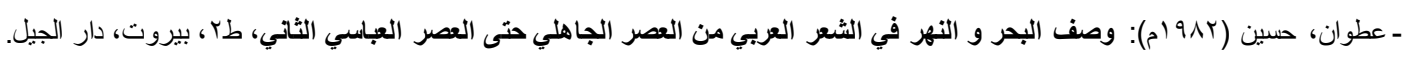

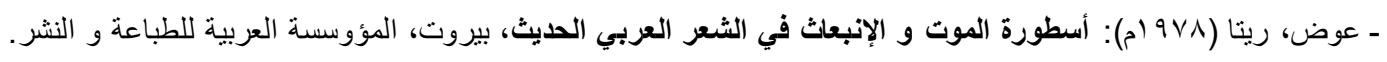

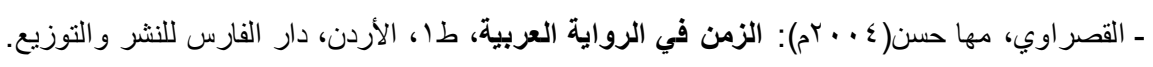

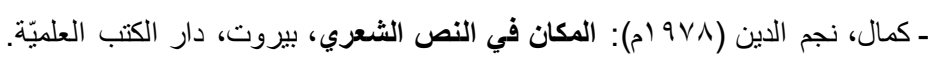

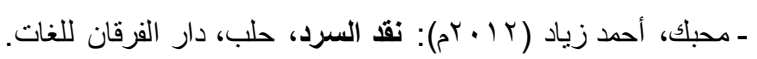

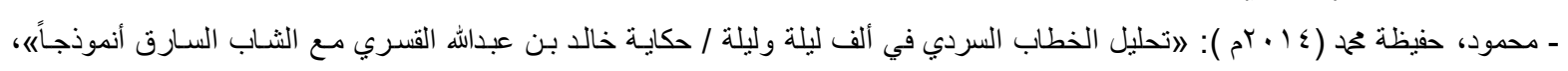

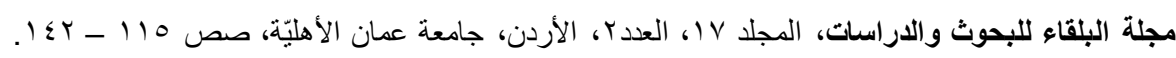

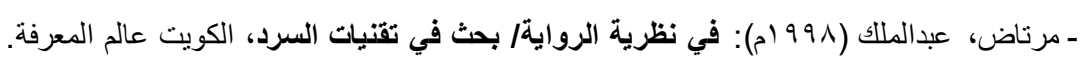

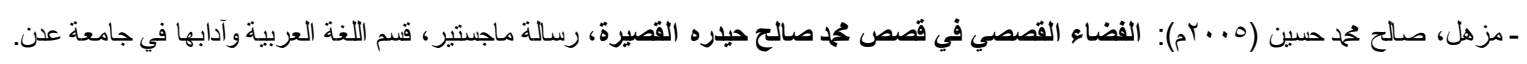

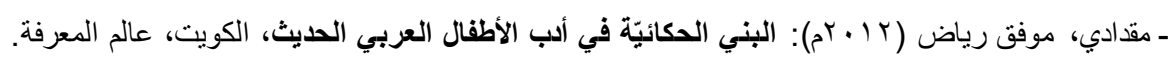

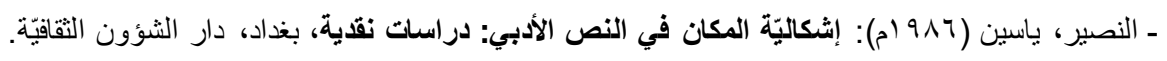

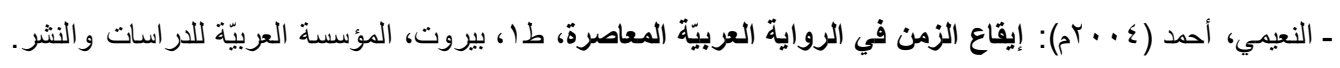
http://www.marefa. org/index.php/\%D8\%A3\%D8\%BA\%D9\%86\%D9\%8A\%D8\%A9_\%D8\%A7\%D9\%84\%D8\%A8\%D8\%AC\%D8\%B9\%D8\%A9

اعد الصنعة ومعايير ها، وخروجا على الإيجاز الذي وسم لغة العرب بميسمه ، فه (العرب) ميالون إلى تكثيف المعاني والتعبير عنها بأقل 